\section{Prof. E. S. Salmon}

After a long illness, Prof. Ernest Stanley Salmon died on October 12 at the age of eighty-eight.

Anyone unfamiliar with mycology might be pardoned for thinking that his reputation rested on the breeding of new varieties of the hop (Humulus lupulus L.). Yet when he came to Wye College (University of London) in 1906, he had already established himself as the authority on an important group of fungi. Researches at the Jodrell Laboratory, Kew, had led to the publication, in 1900, of "A Monograph of the Erysiphaceae", a work which remains fundamental for systematic mycology and which was reproduced as microcards only a few months ago. After further study in the laboratory of Prof. Marshall Ward at Cambridge, he demonstrated the very highly developed specialization of parasitism in the same group; accounts of this may be found in the Transactions of the Royal Society, 1904 and 1905.

Salmon was appointed to Wye College to study diseases of plants and so was probably the first professional plant pathologist in Britain. There were then few helpful text-books, but it was not long before he had combined laboratory work and field oxperiments to good purpose. His first papers, which may even now be read with profit, describe in some detail a selection of the diseases of crop plants; the main emphasis being on apple scab (Venturia inaequalis (Cooke) Wint.) and other pathogens of fruit. Bordeaux mixture and lime sulphur, fungicides which are still in use, were introduced to Kentish orchards, while he conducted a vigorous campaign in the Press and elsewhere which led to the passing of the Destructive Insects and Pests Act in 1907.

He was elected president of the British Mycological Society in 1911; appointed reader in economic mycology in the University of London in 1912, professor of mycology in 1925 and emeritus professor in 1939. He was made Fellow of Wye College in 1948.

When, soon after the First World War, the specialist advisory service in Britain began, he was appointed advisory mycologist of the Wye Province. Until he relinquished this appointment in 1937, he led a series of investigations on diverse plant diseases. Particularly noteworthy are the contributions on fruit and hops with which are associated his colleagues, Drs. H. Wormald and W. M. Ware.

Salmon arranged a programme of hop breeding in 1907 and followed this without a break until his last illness. From the beginning, one of his main aims was to produce varieties with exceptionally high preservative values; such varieties would enable the British grower to compete with imported American hops. In order to have at command a wide range of diverse types, he assembled male and female plants from different parts of the world; this unique col. lection, together with selected progeny, for long occupied about an acre of ground at Wye College. Of the many thousands of seedlings raised, his earliest success was the English-grown American, Brewer's Gold. This was F1 from an English male hop and a wild hop from Morden, Manitoba. Paradoxically, the variety has been more widely grown in Canada and the United States than in Britain. The varieties Bullion and Northern Brewer which have become so popular with the British hop industry during the past decade are $F 1$ and $F 3$ seedlings, respectively, of parents from the same sources. Other seedlings of his raising proved to be tolerant to hop wilt (Verti- cillium albo-atrum Reinke and Berth.) and these have been of great value for planting in infected soil.

In recognition of his work on hops he received in 1955 the Horace Brown Medal, the highest honour which the Institute of Brewing can bestow.

After the manner of the pioneer, Salmon was a strong individualist and, in his later years at least, showed little enthusiasm for gatherings, whether scientific or social. He found relaxation in literature and in his small garden of rare plants.

\section{H. H. Glasscock}

\section{Prof. J. Zenneck}

Prof. Jonathan Zennects, one of the earliest pioneers of radio science, died in Munich in April, a few days before his eighty-eighth birthday. Prof. Zenneck was born in 1871 in Württemberg, Germany, and studied mathematics and natural science at Tübingen, where he obtained his doctorate in 1894 . In the following year he became an assistant in the Physical Institute in Strasburg; he moved to Dantzig in 1905 to become assistant professor, and later (1911) professor of physics in the Institute of Technology. His academic career was continued by his appointment in 1913 to the chair of physics at the Technical High School of Munich, where he remained until his retirement.

Most of the basic contributions of Prof. Zenneck were made in the days when spark transmitters were used for wireless telegraphy, concurrently with the development of high-frequency machines and are generators to produce undamped oscillations for radio-telephony. Among the earliest of his achievements was the establishment of the first radio-link for navigational purposes between Cuxhaven and Heligoland in 1899-1900. His basic experimental and theoretical contributions to wave propagation were of great importance in the early development of wireless communications. He expounded the first theory on wave propagation along the Earth (Zenneck wave) which explained the effect of the ground constants on polarization and absorption of the waves. Also well known are his basic contributions to ionospheric research, which he initiated in Germany; and he was the founder of the first. German ionospheric research station, Herzogstand, in Kochel, Bavaria, which was in operation until 1945.

Dr. Zenneck's interests were not limited to radio. $\mathrm{He}$ also contributed to other areas in the general field of applied physies such as acoustics and gas discharges. He was the author of the first German text-book on wireless telegraphy, "Electromagnetic" Oscillations and Wireless Telegraphy", published in 1906, which was the classic work in this field for many years. $\mathrm{He}$ was also the editor of the Hochfrequenztechnik und Elektroakustik, the leading journal of the world during the early days of radio.

His second book, entitled "Wireless Telegraphy". was published in Germany in 1908, and a second edition appeared four years later. It was translated into English in 1915 by A. E. Seelig, and published in London and New York, forming one of the most useful text-books available to students at that time on the generation, propagation and detection of electromagnetic waves in the radio part of the spectrum.

$\mathrm{He}$ received many honours and medals from academic and professional societies, including an honorary doctor's degree from the Institute of Tech- 
nology at Dresden. He was made a fellow of the Institute of Radio Engineers (N.Y.) in 1915, received its medal of honour in 1928, and was a member of the board of directors and vice-president in 1933 . $\mathrm{He}$ was honorary president of the German National Committee of the International Scientific Radio
Union, and was elected vice-president of that Com. mittee in 1938. All those who had the pleasure of meeting Prof. Zenneck at international conferences will remember his charming personality and his modest simplicity, combined with wittiness and quickness of repartee.
R. L. Sмith-Rose

\section{NEWS and VIEWS}

Nobel Prize for Physics for 1959:

Dr. Emilio Segre and Dr. Owen Chamberlain

Dr. Segre and Dr. Chamberlain, who have been awarded the Nobel Prize for Physics for 1959, have collaborated in research in high-energy physics for a number of years at the Lawrence Radiation Laboratory of the University of California at Berkeley. Dr. Segre was born in Italy in 1905 and was a member of Fermi's remarkable nuclear research school in Rome. He emigrated to the United States before the War. Dr. Chamberlain is thirty-nine and, like Dr. Segre, is a distinguished experimentalist. Their collaboration at Berkeley has been associated with the great accelerators which have been built there over the years. They were the leading members of a team engaged in experiments on nucleon-nuclear interaction with the help of the 184-in. synchrocyclotron, and in particular made a detailed study of polarization phenomena in high-energy scattering. The work which has now been honoured by the Nobel award has, however, been their discovery in 1955 of the antiproton in experiments with the $6 \mathrm{GeV}$.-proton synchrotron, the bevatron. The existence of the antiproton had been confidently postulated for many years ; the discovery of the positron in 1932, and its interpretation on the Dirac theory, also implied the existence of other anti-particles including a negatively charged proton. Antiprotons stubbornly eluded discovery in the very high-energy (but very lowintensity) bombardments of cosmic radiation, and one reason for building the bevatron was to have an intense beam of sufficiently energetic protons to create proton-antiproton pairs in the laboratory.

The actual discovery, however, involved a long series of painstaking experiments with very elaborate detection equipment which had to be specially developed. The development of effective techniques for beam separation and detection for use with machines of very great energy is a field of research in itself. The antiprotons produced when a beam of high-energy protons falls upon a target in a machine like the bevatron are very greatly outnumbered by other charged particles produced with very broad momentum spectra in the relativistic region. These background particles would cause impossible confusion in the detection apparatus if they were not systematically eliminated. Their elimination in the experiments of Segre and Chamberlain was a major programme in experimental physics. The fina] apparatus used was elaborate and refined. Charge and momentum separation of antiprotons from the mixed beam of particles was achieved by magnetic deflexion and focusing in separate lenses, and velocity selection was aided by time-of-flight and Cerenkov radiation techniques. When some forty events had been aceumulated which corresponded within acceptable margins of error with the properties of the antiproton, it could be said that the antiproton had been discovered. As is usual in high-energy research with large machines, team-work by large numbers of physicists and engineers was involved; the award of the Nobel prize to Segre and Chamberlain underlines the fact that the brilliant individual worker is still needed to inspire and direct the work.

\section{Royal Society Medals for 1959}

THE following awards of medals have been made by the President and the Council of the Royal Society : Copley Medal to Sir Macfarlane Burnet, director of the Walter and Eliza Hall Institute, Melbourne, Australia, for his distinguished contributions to knowledge of viruses and of immunology. Davy Medal to Prof. R. B. Woodward, of the Department of Chemistry, Harvard University, Cambridge, Massachusetts, for his distinguished researches in organic chemistry and particularly for his contributions to the structure and synthesis of natural products. Hughes Medal to Dr. A. B. Pippard, reader in physies in the University of Cambridge, for his distinguished contributions in the field of low-temperature physics.

\section{Genetics at Cambridge :}

Prof. J. M. Thoday

A Graduate of the University College of North Wales. Bangor, Dr. J. M. Thoday, who has recently been appointed to the Arthur Balfour chair of genetics in Cambridge, began his research career in the Botany School, Cambridge, under the guidance of Dr. (now Prof.) D. G. Catcheside. These early studies of the action of ionizing radiations on chromosome structure were interrupted by war service in the Royal Air Force, to be resumed after the War at the Mount Vernon Hospital and Radium Institute, where, in collaboration with Dr. J. Read, Thoday demonstrated the effect of oxygen tension on the frequencies of chromosome changes following irradiation. During 1947 he moved to Sheffield to take up an appointment as lecturer in cytogenetics, becoming senior lecturer in charge of the newly founded Department of Genetics there in 1954. In Sheffield his research moved towards the field of population genetics, particularly in relation to the genetical control of stability in development and to the action of disruptive selection. His experiments with Drosophila have been especially rewarding in the light they have thrown on the power of disruptive selection to conserve variability and to build up polymorphisms within populations. They are showing us for the first time under controlled conditions how polymorphisms can come into being and how their genetical structure reflects the selection which has brougbt them about. Prof. Thoday's breadth of experience and originality of approach angur well for the future of genetics in Cambridge.

Genetics at Sheffield : Dr. J. A. Roper

DR. J. A. Roper returns to his own University (Sheffield) as the first holder of the new chair of 